\title{
FíR FLATHEMON IN THE RUSSIAN PRIMARY CHRONICLE? THE LEGEND OF THE SUMMONING OF THE VARANGIANS AND THE PREFATORY MATTER TO AUDACHT MORAINN
}

\author{
DMITRY NIKOLAYEV
}

\section{Introduction}

One of the most hotly disputed questions of medieval Russian history is the interpretation of the so-called legend of the summoning of the Varangians. This legend forms part of the reconstructed Russian Primary Chronicle, also known as the Tale of the Bygone Years, which is deemed to be the source text for all the subsequent Russian annals. Main evidence for the Russian Primary Chronicle (supposedly composed at the beginning of the twelfth century) is produced by the Laurentian and the Ipatian chronicles dating from the fourteenth and fifteenth centuries respectively. Narratives preserved in these chronicles are usually invoked to examine the summoning legend.

I will cite the abridged version of the legend contained in the Laurentian chronicle (Karsky 1926) in a slightly modified translation by Samuel H. Cross and Olgerd P. Sherbowitz-Wetzor (Cross, SherbowitzWetzor 1953) (see full text in the Appendix). The differences in content between this version and the versions in Ipatian and other chronicles are of no importance for the problems under consideration:

Year 6367 (CE 859). The Varangians from beyond the sea imposed tribute upon the Chuds, the Slavs, the Merians, the Ves', and the Krivichians. But the Khazars imposed it upon the Polyanians, the Severians, and the Vyatichians, and collected a white squirrel-skin from each hearth.

Years 6368-6370 (CE 860-862). The tributaries of the Varangians drove them back beyond the sea and, refusing them further tribute, set out to govern themselves. There was no law among them, but tribe rose against tribe. Discord thus ensued among them, and they began to war one against another. They said to themselves, "Let us seek a prince who may rule over us and judge us according to Justice (Rus. po pravu)." They accordingly went overseas to the Varangian, to the Rus'... The Chuds, the Slavs, the Krivichians, and the Ves' then said to the people of Rus', 'Our land is great and rich, but there is no order in it. Come to rule and reign over us.' 
Three brothers were selected, with their kinsfolk, who took with them all the Rus' and migrated. The oldest, Rurik, settled in Novgorod; the second, Sineus, at Beloozero; and the third, Truvor, in Izborsk. ... After two years, Sineus and his brother Truvor died, and Rurik assumed the sole authority...

In the analysis of this episode two approaches were current. One of them may be roughly labeled as 'historical' and the other as 'philological'. The historical approach to this legend - which is the traditional one but which now seems to be rejected by most modern scholars - is to treat the tale of Rurik and his brothers as the genuine truth. The most important question therefrom is to decide either the Varangians were the people who laid the cornerstone of the Russian state or they were merely the invited managers who took places in the already established hierarchy (hence the so-called split between the Normanist vs. the anti-Normanist approaches to the Russian historiography, see Duczko 2004). This problem was hotly debated for nearly two hundred years. However, it partly lost its appeal when the scholars turned to the philological investigation of the chronicles. Soon it became evident that the reconstructed eldest Russian chronicle, the Tale of the Bygone Years, is a conscious literary composition with discernible narrative patterns and political agenda. Therefore, the focus of the recent 'philological' approach was on finding a literary or a folkloric source for the Varangian legend and on explaining its function in the Primary Chronicle.

This quest for the proto-text of the Varangian legend was not altogether successful. The best parallel version found was the story of the summoning of Anglo-Saxons to Great Britain by Vortigern. Here we see invited brothers, only two of them, though, who establish a new royal dynasty, that of the Kingdom of Kent. However, the overall plot is strikingly different, and this story would hardly have been proclaimed the parallel version of the Varangian legend if not for the words of the Saxon chronicler Widukind of Corvey. This author retold the episode of the summoning of Anglo-Saxon war bands to Great Britain basing largely on the work of Bede but infused it with some rhetorical embellishment. Thus, the ambassadors of the Britons not only invite the Saxons, but tell them, 'Terram latam et spatiosam et omnium rerum copia refertam vestrae mandant ditioni parere' ('[Our people] offer you the land which is great and rich', Kehr 1904: 8, my emphasis). This seeming parallel to the words of the Chuds, the Slavs, the Krivichians and the Ves' forced some scholars to conclude that the text of Widukind became via some missing link the source for the Russian Primary Chronicle (Stender-Petersen 1953). Yet this missing link was nearly impossible to establish, and Rurik did not look much like Hengest. Note also the complete absence of any personage similar to Vortigern in the Varangian legend. 
The other way to treat this problem, proposed in the middle nineties by the Russian scholars Vladimir Petrukhin and Yelena Mel'nikova was by means of the genre theory. In their paper on the source of the Varangian legend (Mel'nikova, Petrukhin 1995), the scholars state that the Russian Primary Chronicle is an instance of a medieval pseudo-historical narrative focused on the dynastic history and the aetiology of state as a concept. The demands of the genre cause such narrative patterns as the invitation of a ruler, or his magical birth, or his finding following some wondrous signs to appear. In the authors' view, such narratives were propagated not as a result of textual influence but rather as the workings of literary typology. That starting point enabled Mel'nikova and Petrukhin to adduce quite a few parallels including the legend of Romulus and Remus, the Bohemian tale of Prremysl the Ploughman and some others. Unfortunately, all these texts have so few discernible motifs in common that the comparison becomes nearly pointless and brings us no closer to the understanding of the particular combination of motifs that underlies the Varangian legend. The aim of the present paper is to propose a new parallel text to the Varangian legend until now overlooked by other researchers.

\section{The structure of Sóerchlanda Érenn uile}

This text is the medieval Irish tale of the revolt of the aithechthúatha, the 'vassal tribes', who decided to kill all the noble lineages of Ireland in order to rule for themselves. For the present analysi, it is important to note that this tale often serves as a prefatory matter to the famous speculum regum Audacht Morainn. The short version of the tale which forms part of the B Recension of Audacht Morainn runs as follows:

Incipit Audacht Morainn maic Moin do Fheradach Fhind Fhechtnach mac Craumthainn Niath Náir. Mac side ingine Lóith maic Deleraith di Chruthentúaith. Bert a máthair ass ina brú iar ndílgund tigernae n-Érenn dona haithechthúathaib acht Feradach namá i mbrú a máthar. Do-luid side íarum taris co slógaib 7 foídis Morann in n-audacht-so cucci.

Here begins the Testament of Morann son of Móen to Feradach Find Fechtnach son of Craumthann Nia Nár. He was the son of the daughter of Lóth son of Delerath of the Picts. His mother brought him away in her womb after the vassal tribes had destroyed the nobles of Ireland except for Feradach in his mother's womb. He came over afterwards with hosts and Morann sent this Testament to him (Kelly 1976: 2-3). 
Here we see virtually nothing that can provoke comparison with the Varangian legend. However, quite a few relevant motifs are contained in the longer version of this prologue, which was edited by Rudolf Thurneysen (1917) with the A Recension of Audacht Morainn.

This longer version belongs to the Middle Irish period and is apparently of a much later date than Audacht Morainn itself. It is also later than the short introduction in Recension B. It consists of two parts: a lengthy historical poem Sóerchlanda Érenn uile and a prose elaboration on the material of this poem. The relevant sections of the poem go as follows:

1. The noble lineages of the whole of Ireland / they were all killed by one man / except for three sons... they escaped Cairpre. 2. The pregnant ones fled from him to the East... so they were born there in the Eastern country / after they came to Scotland... 7. They made a fair counsel / the vassal tribes of Ireland at that time / because it was a deprivation for them of all kinds: / of grain, milk, tree mast and other plants.

8 . On this counsel they decided - / they had repentance of what they performed $-/$ to send a call to the sons - the clear deed - / in order to proclaim them the high-kings.

9. They gave a firm pledge / the vassal tribes of Ireland / according to the will of the sons who were in the East / to make them return from Scotland.

10. These are the pledges that they gave then: / the sky, the earth, the beautiful sun, / that everything would be according to their will from one mountain to the other / until there is the sea around Ireland.

11. Conn, Eogan, noble Arade / they are the descendants of the three rulers / Arade - in Emain without blemish, / Conn Cetchatach - in Temair.

12. Eogan on the Caisil of kings / there his lineage established itself. / So its with these dynasties, here and there, / that every historian should correlate every noble lineage. ${ }^{1}$

The prose text of the prologue follows the sequence of events as presented in the poem but adds some additional detail.

Unfortunately, we cannot be sure that these facts formed part of the original revolt legend, which underlies Sóerchlanda Érenn uile. We read:

\footnotetext{
${ }^{1}$ The English translation is my own based on Thurneysen 1917: 56-7; see full text and translation in the Appendix.
} 
Bai fodord mor ic athechthuathaib Erenn $i$ n-aimsir tri rig $n$ Erenn .i. Fiacho Findolaig ${ }_{7}$ Feic mac Fideic Caich ${ }_{7}$ Bres mac Firb. <... > Ba hadbal tra ${ }_{7}$ ba dírím truma in chísa ${ }_{7}$ met na cana 7 fortamlaighe in fhlaithiusa laisna tri ríghaibh sin for aitheachaib Erend. <...> Ba sí iarom comairle ro-chinnset ann sin .i. fledh do thargud do thig Cairpri Chinn Chait i. co Bruidin Maic Da-Réo i mBreifne 7 a tigernadhu do thochuiriudh chuici do shaighidh na fleidhe ${ }_{7}$ bás do immbeirt forro ${ }_{7}$ in ríge do beith acu fein. <...> Fuair Corpre bás iar tain 7 tarcatur fir Erenn righe do Morann dia mac. Ro-ráidh immurro Morann nagebadh hi, ar nírbo toich dó $i$. 'Ceist cidh do-genam diu' ar iat. 'Ro-fetur sa' ar Morann 'ani as coir ann i. tri comarbai Erenn filet a nAlbain .i. Feradhach Find Fechtnach ${ }_{7}$ Corb Aulom 7 Tipraite Tireach, 7 tiagar ara cenn da ríghadh uainde, air is dóibh as toich'. - 'Is maith amhlaidh' or cach (Thurneysen 1917: 60-9).

There was a great murmur among the vassal tribes of Ireland in the time of the three kings: Fiachu Finnolach, Feig son of Fideg Caich, and Bress son of Ferb... The burden of tax, and the amount of tribute, and the hardness of the rule of these three kings were great and unbearable for the vassal tribes of Ireland... This was the project that they invented at that time: to arrange a feast at the house of Cairpre Cindchat, that is in the hostel of DaRéo in Breifne, and to invite the lords to partake of it, and to kill them in order to have all the authority to themselves... Afterwards Coirpre died, and the men of Ireland proposed Morann, his son, to take the kingdom. Morann, however, said that he cannot accept it since it is not his by right. "What should we do then?" they asked. "I know," said Morann. "Those who have the right, they are the three heirs of Ireland who dwell in Scotland: Feredach Find Fechtnach, Corb Aulomm, and Tipraide Tirech. You should send to them in order to place the kingdom in their hands, since it is theirs by right." "That would be right," said everybody (the English translation is my own).

The heirs return and make the same pact with the vassal tribes as the one described in the poem. In the introduction as it stands, the poem is attached at the end of the prose text to corroborate the information contained in it. 


\section{Comparison of Sóerchlanda Érenn uile with the Varangian legend in Russian Primary Chronicle and some preliminary conclusions}

It seems that the tale of the rebellion of the vassal tribes and of the subsequent return of the rulers can be schematised as follows:

1. A group of tribes is in a state of dependence towards some ruling class, which is not of the same stock as themselves. That is, the noble lineages of Ireland are not the noble lineages of the vassal tribes: for some reason the vassal tribes had lost their own ruling dynasties and afterwards were obliged to pay tribute to kings of other túatha.

2. Being dissatisfied with the state of affairs, the vassal tribes overthrow the ruling class which is massacred except for three pregnant women who flee from Ireland overseas to Scotland.

3. The vassal tribes left with no proper ruler try to govern themselves, but they suffer hardships on account of their crime ('it was a deprivation for them of all kinds: of grain, milk, tree mast and other plants').

4. After having lived for some time in these circumstances, the vassal tribes are overcome with repentance for what they had done and decide to install proper rulers who can be accepted by the land of Ireland.

5. The envoys sent overseas ask the princes to return to Ireland.

6 . The three princes and the vassal tribes constitute a pact.

7. The new kings divide Ireland among themselves and become the ancestors of the Irish ruling dynasties.

It appears that the legend of the summoning of the Varangians can be schematised in the same way without losing its any essential constituent parts:

1. A group of tribes is in a state of dependence towards some ruling class, which is not of the same stock as themselves:

'The Varangians from beyond the sea imposed tribute upon the Chuds, the Slavs, the Merians, the Ves', and the Krivichians.'

2. Being dissatisfied with the state of affairs, the vassal tribes overthrow the ruling class which is forced to flee overseas:

'The tributaries of the Varangians drove them back beyond the sea...' 
3. The vassal tribes left with no proper ruler try to govern themselves, but are unsuccessful: '...refusing them further tribute, [they] set out to govern themselves. There was no law among them, but tribe rose against tribe. Discord thus ensued among them, and they began to war one against another.'

4. The vassal tribes have repentance for what they had done and decide to find a proper ruler: "They said to themselves, "Let us seek a prince who may rule over us and judge us according to the Justice."”

5-6. The envoys sent overseas ask the rulers to come to Rus':

'They accordingly went overseas to the Varangian to the Rus'... "Our land is great and rich, but there is no order in it. Come to rule and reign over us."”

It is to be noted that for Mel'nikova and Petrukhin (1995: 54) this episode is also the moment of the establishment of a pact. They see Russian equivalents of the verbs 'rule' and 'reign' (Rus. knyazhit'; volodet') as legal terms which point to the fact that this pact was not an invention of the chronicler but a genuine historical fact. It seems, however, that this is not a conclusive argument. In the Irish text, the vassal tribes give pledges (OI rátha) to the new rulers. The word ráth is a well-established legal term in the Old Irish legal tradition, and still this does not render the episode all the more historical. Nevertheless, it seems reasonable to stress the importance of the motif of a treaty in this text. Apparently, it is significant that in the beginning of the summoning tale the Varangians merely exacted tribute from Slavic tribes. This does not suggest a state of chaos, but we may speak of a substitution of a new and better treaty for the old state of affairs.

7. The new kings divide the land in three parts among themselves, and one of them becomes the ancestor of the Russian ruling dynasty: 'The oldest, Rurik, located himself in Novgorod; the second, Sineus, at Beloozero; and the third, Truvor, in Izborsk. ... After two years, Sineus and his brother Truvor died, and Rurik assumed the sole authority.'

These apparent and strong similarities between the two tales of overthrowing and re-establishing of ruling elite induce us to consider three different questions: 
(a) First, how this similarity is to be explained?

(b) Secondly, does it shed any light on the Irish text?

(c) Thirdly, should we not reconsider the meaning of the relevant episode in the Russian Primary Chronicle?

In discussing the origin of this similarity, it is important to note that the two texts are representatives of roughly the same genre: the aetiology of the ruling dynasty and of the political system as a whole. Here I follow the typological hypothesis of Mel'nikova and Petrukhin. Also, if we wish to follow the typological line we can notice that the tale of Feradach as contained in the prologue to Recension A of Audacht Morainn is only one of the two versions of the tale of the vassal tribes. Accordingly, we can suppose that it was an instance of recombination of a set of motifs that produced these two versions, and, consequently, that they both have nothing in common with the Russian chronicle except for those motifs.

However, it is hardly possible from a purely statistical point of view for an instance of free recombination of not less than seven motifs to produce two structurally identical texts in two different traditions. Additionally, we can take into consideration the fact that the notion of the law of the ruler, the fir flathemon concept which plays central part in Audacht Morainn, Togail Bruidne Dá Derga (Knott 1936), and in some later texts such as the saga about the king Niall Frossach from the Book of Leinster (Wiley 2005), has some peculiar characteristics in the Irish tale of the vassal tribes. There it has nothing to do with justice or judgments and is simply a property of royal succession or stable political system. Unfortunately, the number of missing links between the Irish and the Russian texts is too overwhelming to make any plausible suggestions as to the origin and the dissemination of the tale of overthrowing and summoning of a ruler. ${ }^{2}$

${ }^{2}$ Cf. an ideologically analogous though structurally different episode from The Life of Apollonius (between 217 and 238 AD) by Flavius Philostratus: "There was then," [Apollonius] said, "a time when the Ethiopians, an Indian race, dwelt in this country, and when Ethiopia as yet was not; but Egypt stretched its borders beyond Meroe and the cataracts, and on the one side included in itself the fountains of the Nile, and on the other was only bounded by the mouths of the river.

Well, at that time of which I speak, the Ethiopians lived here, and were subject to King Ganges, and the land was sufficient for their sustenance, and the gods watched over them; but when they slew this king, neither did the rest of the Indians regard them as pure, nor did the land permit them to remain upon it; for it spoiled the seed which they sowed in it before it came into ear, and it inflicted miscarriages on their women, and it gave a miserable feed to their flocks; and 
Turning to the analysis of the Irish text we see that the narrative device of 'natural punishment' turned from an unjust king to his felonious people seems to be one of the means of resolving the problem of regicide, which was widely discussed in the Middle Irish period (see O'Connor 2006). Thus, as Ralph O'Connor shows (2006: 142), in Immram Snégdusa ocus Maic Riagla written not long after 1090, the same crime is not actually punished: sixty couples of Fir Rois tribe who had killed their oppressive king Fíachu were set adrift in the sea and eventually received by God in the blessed isles where Enoch and Elijah live.

Finally, I suppose that the traditional interpretation of the tale of the summoning of the Varangians as a simple exposition of the beginnings of the Russian state can be corrected. Perhaps, it is not only an aetiological tale, but also a moral tale: the established political order cannot be changed by force, and the ruler cannot be chosen from among the base unruly people themselves. The tale of the origin of the ruling dynasty, which was to thrive in Russia up to the times of the political turmoil at the beginning of the seventeenth century, also had a legitimising aspect to it: the dynasty did not simply appear, but it was the only rightful one, and its claim on the peoples of Rus' was supported not only by the traditional, but also by the supernatural sanction.

Russian State University for the Humanities, Moscow

wherever they tried to found a city, it would give way sink down under their feet. Nay more, the ghost of Ganges drove them forward on their path, a haunting terror to their multitude, and it did not quit them until they atoned to earth by sacrificing the murderers who had shed the king's blood with their hands.

Now this Ganges it seems, was ten cubits high, and in personal beauty excelled any man the world had yet seen, and he was the son of the river Ganges; and when his own father inundated India, he himself turned the flood into the Red Sea, and effected a reconciliation between his father and the land, with the result that the latter brought forth fruits in abundance for him when living, and also avenged him after death..."' (Conybeare 1912, vol I: 271-273). 


\section{Appendix}

1. Full Old Russian text of the summoning legend from the Laurentian chronicle (Karsky 1926):

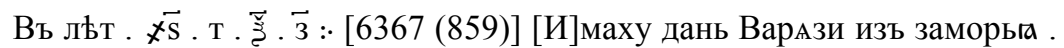
на Чюди и на Словънех . на Мери . и на всьхъ Кривичъхъ . а Козари имаху на ПолАнъ $\widehat{x}$. и на Съверьर्र и на Вятичъхъ . имаху по бъльи

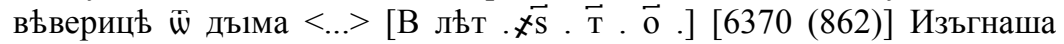
Вардги за море и не даша имъ дани . и почаша сами в собъ володъти . и не бъ в нихъ правдъ1 . и въста родъ на родъ . [и] быша в нихิ усобицъ. и воєвати почаша сами на са [и] рђша сами в себђ . поищемъ собъ кнАЗА . иже бъ1 володЬлъ нами . и судиЛъ по праву . [и] идаша за море къ ВарАгомъ к Рус1 . сице бо са звахуть и . варАзи суть . гако се друзии зъвутса Свое . друзии же Оурмане . АнъглАне друзии Гъте . тако и си рђша . Русь . Чюдь [и] Словъни . и Кривичи. всА землА наша велика и шбилна . а нарАда в неи нътъ. да поидъте кНАЖитъ и володъти нами . и изъбращасА . $\vec{\Gamma}$. братьґ. с родъ своими. [и] погша по собъ всю Русь . и придоша старђишии Рюрикъ [сьде Новъгородъ] . а другии Синеоусъ на Бъльшзерђ . а третии Изборьсть . Труворъ . [и] $\bar{w}$ тbхъ [Варагъ] прозваса Рускага земла Новугородьци ти суть людьє Нооугородьци $\bar{w}$ рода ВарАжьска . преже бо бъша Словъни . по дву же льту . Синеоусъ оумре . а брать єго Труворъ . и приг власть Рюрикъ . и раздага мужемъ своимъ градъ . швому Полотескъ швому Ростовъ другому БЪлошзеро . и по тъмъ городомъ суть находници ВарАзи а перьвии насельници в Новъгородъ Словъне . [въ] Полотьски Кривичи . в Ростовь МерА . в БЪлъшзерђ Весь . в Муромъ Мурома . и тьми всьми шбладаше Рюрикъ.

2. English translation (following Cross, Sherbowitz-Wetzor 1953):

Year 6367 (859). The Varangians from beyond the sea imposed tribute upon the Chuds, the Slavs, the Merians, the Ves', and the Krivichians. But the Khazars imposed it upon the Polyanians, the Severians, and the Vyatichians, and collected a white squirrel-skin from each hearth.

6368-6370 (860-862). The tributaries of the Varangians drove them back beyond the sea and, refusing them further tribute, set out to govern themselves. There was no law among them, but tribe rose against tribe. Discord thus ensued among them, and they began to war one against another. They said to themselves, "Let us seek a prince who may rule over us and judge us according to the Justice." They accordingly went overseas to the Varangian, to the Rus': because they were called so and they were Varangians, just as some are called Swedes, and others Normans, English, and Gotlanders. The Chuds, the Slavs, the Krivichians, and the Ves' then said to the people of Rus', "Our land is great and rich, but there is no order in it. 
Come to rule and reign over us." Three brothers were selected, with their kinsfolk, who took with them all the Rus' and migrated. The oldest, Rurik, located himself in Novgorod; the second, Sineus, at Beloozero; and the third, Truvor, in Izborsk. On account of these Varangians, the district of Novgorod became known as the land of Rus'. The present inhabitants of Novgorod are descended from the Varangian race, but aforetime they were Slavs. After two years, Sineus and his brother Truvor died, and Rurik assumed the sole authority.

He assigned cities to his followers, Polotsk to one, Rostov to another, and to another Beloozero. In these cities there are thus Varangian colonists, but the first settlers were, in Novgorod, Slavs; in Polotsk, Krivichians; at Beloozero, Ves', in Rostov, Merians; and in Murom, Muromians. Rurik had dominion over all these districts.

\section{Sóerchlanda Érenn uile (Thurneysen 1917: 56-7):}

1. Soerchlanda Erenn uile ro-marbtha la oenduine acht na tri maic monar ngle at-rullatar o Choirpre.

2. Torrcha at-rullatar uadh sair a maithrecha na mac sin conid and ructha is tír thair íar ríachtain doib i n-Albain.

3. Feradach Find Fechtnach Fail

Corb Aúlom a Mumain mair is Tipraite Tírech thall it é sin a comanmann.

4. Ingen ríg Alban cen ail ba sí mathair Feradaig Bane ba hed ainm na mna ingen Luaith meic Darera.

5. Crufe ingen Gartníat gluair ro-gab Bretnu cosin mbuaid maithir Coirb Auloim cen ail as a sil fil i Mumain. 
6. Ingen rig Saxan ní sneid maithir in Tipraiti thréin Ane a ainm oca a taig ingen cuinde Cainídail.

7. Do-ronsat comairli cain athig Erenn in tan sin uair tallad forro as cach mud ith blicht mes ocus torud.

8. 'Sí comairle ro-chinnset aithrech léo aní ro-millset togairm na mac monar nglé dia n-oirdned i n-airdrige.

9. Do-ratsat ratha co tenn athechthúatha na hÉrenn im réir na mac batar tair acht co-tístais a hAlbain.

10. It é ratha tucsat ind nem talam ésca grian grind immo reir a beinn i mbeinn cein maras muir im Erinn.

11. Cond Eogan Araide an it é ciniud na tri mál Araide i n-Emain cen ail Cond Cétchthach i Temair.

12. Eogan i Caisiul na rig is and tarastar a shil conid fríu sin síu is tall samlas in suí cach soerchland.

4. English translation:

1. The noble lineages of the whole of Ireland / they were all killed by one man / except for three sons - the clear deed -/ they escaped Cairpre.

2. The pregnant ones fled from him to the East / these mothers of these sons / so they were born there in the Eastern country / after they came to Scotland.

3. Feredach Find Fechtnach of Ireland / Cord Aulomm from great Munster / and Tipraide Tirech there / These are their nicknames. 
4. The daughter of the king of Scotland without blemish / she was the mother of Feredach / Baine, that was the name of the woman / the daughter of Luath son of Darera.

5. Cruibe, the daughter of the splendid Gartnia, / she captured the Britons with this victory, / the mother of Corb Aulomm without blemish / her descendants live in Munster.

6. The daughter of the king of the Saxons - that is not insignificant - / the mother of the strong Tipraide / Aine was her name when she fled / surrounded by maidservants daughter of Camdal.

7. They made a fair counsel / the vassal tribes of Ireland at that time / because it was a deprivation for them of all kinds: / of grain, milk, tree mast and other plants.

8. On this counsel they decided $-/$ they had repentance of what they performed - / to send a call to the sons - the clear deed $-/$ in order to proclaim them the high-kings.

9. They gave a firm pledge / the vassal tribes of Ireland / according to the will of the sons who were in the East / to make them return from Scotland.

10. These are the pledges that they gave then: / the sky, the earth, the beautiful sun, / that everything would be according to their will from one mountain to the other / until there is the sea around Ireland.

11. Conn, Eogan, noble Arade / they are the descendants of the three rulers / Arade - in Emain without blemish, / Conn Cetchatach - in Temair.

12. Eogan on the Caisil of kings / there his lineage established itself. / So its with these dynasties, here and there, / that every historian should correlate every noble lineage.

\section{References}

Conybeare, F. C., trans. and ed., 1912, The Life of Apollonius of Tyana: The Epistles of Apollonius and the Treatise of Eusebius, in 2 vols., London.

Cross, S. H., \& Sherbowitz-Wetzor, O. P., trans. and eds., 1953, The Russian Primary Chronicle: Laurentian Text, Cambridge, Mass.

Duczko, W., 2004, Viking Rus. Studies on the Presence of Scandinavians in Eastern Europe, Leiden.

Karsky, Ye. F., ed., 1926, Polnoye sobraniye russkikh letopisey. Tom I: Lavrent'jevskaja letopis', Leningrad. 
Kehr, A., ed., 1904, Widukindi Monachi Corbeiensis Rerum Gestarum Saxonicarum Libri Tres. Hannoverae et Lipsiae (Editio Quarta).

Kelly, F., ed. and trans., 1976, Audacht Morainn, Dublin.

Knott, E., ed., 1936, Togail Bruidne Dá Derga, Dublin.

Mel'nikova Y., Petrukhin V., 1995, 'Legenda o prizvanii varyagov i stanovlenije drevnerusskoj istoriographii' [Legend relating to the Summoning of the Varangians and the Foundation of the Early Russian Historiography], Voprosy istorii 2, 44-57.

O'Connor, R., 2006, 'Searching For The Moral in Bruiden Meic Da Réo', Ériu 56,117-43.

Stender-Petersen, A., 1953, Varangica, Aarhus.

Thurneysen R., 1917, 'Morands Fürstenspiegel', ZCP 11, 56-106.

Wiley, D., 2005, 'Niall Frossach's True Judgement', Ériu 55, 19-36. 